Discussion Paper No. 12-027

Productivity Effects of Basic Research in Low-Tech and High-Tech Industries

Dirk Czarnitzki and Susanne Thorwarth

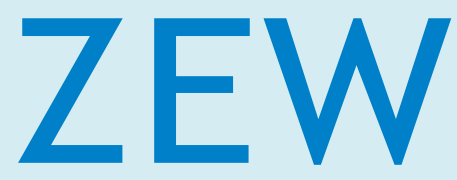

Zentrum für Europäische Wirtschaftsforschung $\mathrm{GmbH}$

Centre for European

Economic Research 
Discussion Paper No. 12-027

\section{Productivity Effects of Basic Research in Low-Tech and High-Tech Industries}

Dirk Czarnitzki and Susanne Thorwarth

Download this ZEW Discussion Paper from our ftp server:

http://ftp.zew.de/pub/zew-docs/dp/dp12027.pdf

Die Discussion Papers dienen einer möglichst schnellen Verbreitung von neueren Forschungsarbeiten des ZEW. Die Beiträge liegen in alleiniger Verantwortung der Autoren und stellen nicht notwendigerweise die Meinung des ZEW dar.

Discussion Papers are intended to make results of ZEW research promptly available to other economists in order to encourage discussion and suggestions for revisions. The authors are solely responsible for the contents which do not necessarily represent the opinion of the ZEW. 


\section{Non-technical Summary}

Research and development activities encompass a myriad of activities which are usually summarized under the terms of basic research, applied research and development. By contrast to applied research and experimental development which focus on the use of existing scientific principles and draw on existing knowledge, basic research is regarded as very early stage research that is driven by a scientist's curiosity or interest in a scientific question and barely helps practitioners with their everyday concern. Its research outputs, however, are considered as key inputs for further investments into the R\&D process which eventually lead to technological innovations, i.e. new products or processes.

As basic research is less focused, more uncertain than the other components of R\&D, and regarded as relatively difficult to appropriate, firms may need a substantiated knowledge base for guidance in order to make these research efforts beneficial. Especially for firms operating in high-tech industries basic research is regarded as an essential component for firm success. Furthermore, as high-tech companies are characterized by investing a larger share of their budgets into $R \& D$ activities they may be able to appropriate a larger fraction of the benefits than firms active in low-tech sectors.

Using a panel database of Flemish firms this study investigates the effect of basic research in low-tech and high-tech industries by estimating augmented Cobb-Douglas production functions. The results show a positive effect of basic research on firm success for the full sample of firms and also for the high-tech sample. Moreover, the results indicate that basic research exhibits a productivity premium when compared to applied research and development in high-tech sectors. In low-tech sectors, however, we do not find evidence for a premium of basic research. 


\section{Das Wichtigste in Kürze (Summary in German)}

Forschungs- und Entwicklungsaktivitäten umfassen eine Vielzahl an Tätigkeiten, die in der Regel unter den Begriffen Grundlagenforschung, angewandte Forschung und experimentelle Entwicklung zusammengefasst werden. Im Gegensatz zur angewandten Forschung bzw. der experimentellen Entwicklung, die eher auf die Verwendung bereits existierender wissenschaftlicher Prinzipien bzw. deren praktischer Umsetzung abzielen, dient die Grundlagenforschung der Gewinnung neuer wissenschaftlicher Erkenntnisse und der Erweiterung der Wissensbasis ohne dabei durch einen direkten praktischen oder industriellen Nutzen motiviert $\mathrm{zu}$ sein. Grundlagenforschung ist jedoch ein wichtiges Element im unternehmerischen FuE-Prozess, da es die Basis für weitere FuE-Aktivitäten bildet, die schließlich zu technologischen Innovationen, d.h. neuen Produkten oder Prozessen, führen.

Da Grundlagenforschung in der Regel eine höhere Unsicherheit als andere FuE-Aktivitäten aufweist und auch als relativ schwierig industriell zu verwerten gilt, brauchen Unternehmen eine fundierte Wissensbasis um die wissenschaftlichen Erkenntnisse nutzbringend im Innovations- und Produktionsprozess einzusetzen. Besonders Firmen aus Hochtechnologiesektoren, für die Grundlagenforschung eine wichtige Komponente hinsichtlich ihres Unternehmenserfolgs darstellt, investieren einen größeren Anteil ihres Budgets in FuE-Aktivitäten und könnten daher in der Lage Erkenntnisse aus der Grundlagenforschung besser zu verwerten als Unternehmen aus anderen Sektoren.

Anhand einer Längsschnittdatenbank flämischer Unternehmen zeigt die vorliegende Studie mittels ökonometrischer Schätzungen erweiterter Cobb-Douglas-Produktionsfunktionen, dass Grundlagenforschung einen positiven Effekt auf den Unternehmenserfolg im Hochtechnologie-Segment hat. Das Ergebnis findet sich auch für die gesamte Stichprobe, jedoch nicht für Unternehmen aus dem Niedrigtechnologie Sektor. Des Weiteren implizieren die dargestellten Ergebnisse, dass gerade in Hochtechnologieindustrien Grundlagenforschung im Vergleich zu angewandter Forschung und experimenteller Entwicklung einen vielfach größeren Effekt auf die betriebliche Produktivität aufweist. Für Firmen aus Niedrigtechnologiesektoren ist dies nicht der Fall. 


\title{
Productivity Effects of Basic Research in Low-Tech and High-Tech Industries
}

- a revised version of this paper is forthcoming in Research Policy -

\author{
Dirk Czarnitzki $^{\mathrm{a}, \mathrm{b}, \mathrm{c}}$ and Susanne Thorwarth ${ }^{\mathrm{a}, \mathrm{c}, \mathrm{d}}$ \\ ${ }^{a}$ K.U.Leuven, Dept. of Managerial Economics, Strategy and Innovation \\ ${ }^{b}$ Centre for R\&D Monitoring at K.U.Leuven \\ ${ }^{c}$ Centre for European Economic Research (ZEW), Mannheim \\ ${ }^{d}$ Monopolies Commission, Bonn, Germany
}

This version: March 2012

\begin{abstract}
R\&D encompasses plenty of activities which are usually summarized under the terms of basic research, applied research and development. Although basic research is often associated with low appropriability it provides the fundamental basis for subsequent applied research and development. Especially in the high-tech sector basic research capabilities are an essential component for a firm's success. We use firm-level panel data stemming from Belgian R\&D surveys and apply a production function approach which shows that basic research exhibits a premium on a firm's output when compared to applied research and development. When we split the sample into high-tech and low-tech companies, we find a large premium of basic research for firms in high-tech industries, but no premium in low-tech sectors.
\end{abstract}

Keywords: $\quad$ Basic Research, R\&D, Production Function Estimation JEL-Classification: L23, O30, O33

\section{Contact:}

Dirk Czarnitzki, K.U.Leuven, Dept. of Managerial Economics, Strategy and Innovation, Naamsestraat 69, 3000 Leuven, Belgium;

E-Mail: dirk.czarnitzki@econ.kuleuven.be; Phone: +32 16326 906; Fax: +32 16326732

Susanne Thorwarth, Monopolies Commission,

Heilsbachstraße 16, 53123 Bonn, Germany

E-Mail: Susanne.Thorwarth@monopolkommission.bund.de; Phone: +49 22833888242

* The authors thank Rene Belderbos, Michele Cincera, Georg Licht, Reinhilde Veugelers and participants of the EARIE 2010, Istanbul, and the ZEW Workshop "Issues in Innovation \& Competition", Mannheim, for helpful comments. 
"The important thing is not to stop questioning. Curiosity has its own reason for existing."

Albert Einstein

\section{Introduction}

It has been widely acknowledged by the literature that research and development have positive effects on firm performance (see Hall et al. 2010 for a recent survey). However, the term $R \& D$ is a rather complex construct, since $R \& D$ encompasses plenty of activities. According to the definition of the Frascati Manual (1993) which frames the methodology for collecting and using statistics about R\&D in OECD countries, the term R\&D covers three activities: basic research, applied research and experimental development.

Basic research can be understood as very early stage research which is designed to build a knowledge base in order to understand fundamental principles. It is driven by a scientist's curiosity or interest in a scientific question. Contrary to applied research and experimental development which are more commercially orientated, basic research is phenomena oriented, that is, it barely helps practitioners with their everyday concern. Nevertheless, it stimulates new ways of thinking which may lead to generation of pioneering and revolutionary ideas, concepts and applications. For instance, modern computer technology could not exist without pure mathematical research, at that point of time undertaken without any ulterior motive of practical applications in computer science. Firms conducting basic research broaden their knowledge base that provides the fundamental basis for subsequent applied research and development. Thus basic research enables a firm to exploit rapidly useful scientific and technological knowledge through their own innovations (Cohen and Levinthal 1989, 1990, Rosenberg 1990). There are several studies (e.g. Mansfield 1980, Griliches 1986) which have already demonstrated that corporate basic research is important for a firm's performance.

Rosenberg (1990) has pointed out that there are a number of activities that are essential to the success of firms located in the high-tech industries that depend heavily upon basic research capability. Therefore, an interesting question arising within this context is how basic research contributes to firms located in different industries. To be more precise, do firms operating in the low-tech sector benefit as much as companies from the high-tech sector by conducting basic research? 
The conventional view of basic research also rests on the assumption that basic research is relatively difficult to appropriate. Basic research is thought to be of riskier nature and also have longer lead times than applied research and development which coincides with lower appropriability (Trajtenberg et al. 1992). As high-tech companies are characterized by investing a larger fraction of their budget in $R \& D$ activities they may be more likely to appropriate a larger fraction of the benefits than firms operating in low-tech sectors.

This paper addresses this question by estimating an augmented Cobb-Douglas production function with Flemish firm level data. Our results indicate that basic research exhibits a productivity premium when compared to applied research and development in high-tech sectors. In low-tech sectors, however, we do not find evidence for a premium of basic research.

\section{Conceptual Framework}

\subsection{Basic Research and the Low vs. High Tech Industry}

Early work (Nelson 1959, Arrow 1962) has already stressed that knowledge once produced has the characteristics of a public good since it may easily spill over from the innovating firm to its rivals allowing them to free ride on its innovative efforts. These outgoing spillovers make it impossible for firms to fully appropriate the economic benefits from their $R \& D$ activities. Nevertheless, there is a vast body of literature which deals with the relationship of R\&D and productivity (see e.g. Mairesse and Sassenou 1991 for a survey and Griliches 1979, 1986, Cuneo and Mairesse 1984, Griliches and Mairesse 1984, Hall and Mairesse 1995, to name only some of the authors who conducted studies at the firm-level). They all provide evidence that a firm's productivity is positively related to research and development.

Especially for firms located in the high-tech industries R\&D activities are crucial to maintain their competitiveness since products and processes are frequently changing in this industry segment. Additionally, within high-tech sectors corporate R\&D investment may be more fruitful in terms of achieving productivity gains. Usually most of the R\&D activities are conducted in the sectors labeled as "high-tech" industries, e.g. around 80 percent of Flanders' total $R \& D$ expenditures have been conducted by firms located in the high-tech segment (Andries et al. 2009). 
Cuneo and Mairesse (1984) used a sample of 182 R\&D performing firms in the French manufacturing sector during the 1972-1977 period to examine the relationship between $R \& D$ and productivity. They distinguished between so-called scientific firms belonging to the R\&D-intensive industries and other firms. The estimated elasticity between productivity and R\&D capital was twice as much for the scientific firms than for firms belonging to other sectors. Griliches and Mairesse (1984) found similar results by applying the same method to a sample of 133 US R\&D performing firms. Harhoff (1998) investigated the relationship between $R \& D$ and productivity in German manufacturing firms using a panel database covering the years from 1979 to 1989 . His results show that the R\&D elasticity differs considerably between high-technology and other firms. Furthermore, a recent study conducted by Tsai and Wang (2004) in which a sample of 156 large Taiwanese firms in the period from 1994 to 2000 is analyzed also leads to the conclusion that the R\&D elasticity is remarkable higher for firms in the high-tech sector. Verspagen (1995) analyzed 15 manufacturing sectors in 9 OECD countries by applying a translog production function. His findings suggest that $R \& D$ only has a positive and significant effect on productivity in hightech industries, but plays no role in the medium and low-tech sectors. Similar to the last study, Kafourous (2005) also used firm-level data of the UK manufacturing sector and found that $R \& D$ investment only has a positive and significant effect in high-tech sectors, whereas it shows no impact in low-tech industries.

\subsection{Why Basic Research?}

According to the Frascati Manual (1993) which is used to create the questionnaire for the OECD R\&D surveys basic research is defined as "[...] experimental or theoretical work undertaken primarily to acquire new knowledge of the underlying foundation of phenomena and observable facts, without any particular application or use in view." This forms a contrast to applied research which focuses on the use of existing scientific principles with the intention to improve existing or create new products and processes and experimental development which draws on existing knowledge gained through research. Since basic research is conducted with no specific application or use in view, the generated knowledge and technologies are potentially applicable elsewhere. The researcher himself may not be able to think about possible applications and may thus miss opportunities to appropriate the potential benefits of the generated knowledge. Due to this vague nature basic research is 
characterized by a higher degree of risk and uncertainty compared to applied research and development and more likely to spill over to competitors. Hence, a profit seeking firm may not capture all of the benefits of basic research which it sponsors leading to an under invest in this type of research, i.e. less than socially desirable (see e.g. Nelson 1959, Pavitt 1991). But what actually makes basic research economically useful? Why is it in the interest of society to support basic research?

As already pointed out above the outputs generated by basic research do barely possess any intrinsic economic value, nevertheless basic research is often considered as the 'fuel that powers innovation'. Its research outputs are considered as key inputs for further investments in the R\&D process which lead to additional research findings and in the optimal case to technological innovations, i.e. new products or processes (David et al. 1992).

Furthermore, investment in basic research can yield technology that can be profitably sold or licensed to others. Secondly, basic science has an impact on technology not just through direct knowledge transfers, but also through access to skills, methods and instruments (1991). As a result, basic research generates the capability to absorb external information and improve the productivity of applied R\&D (Cassiman et al., 2002). It contributes to and enhances the stock of knowledge applied research initiatives build on (Henard and McFadyen, 2005). In addition, the very fact that basic research does not have specific goals or applications in mind, permits the direction of a basic research project to change over time, which can lead to significant breakthroughs that are seldom discovered in applied research projects, e.g. a famous example is the case of Pasteur who found the anthrax vaccine by coincidence while actually studying chicken cholera (Nelson, 1959). As a result, basic research can - even in the short-term - lead to breakthrough applications (Pavitt, 1991).

There are some authors who have already advocated that a firm's investment in basic research has a positive impact on its overall performance: in his seminal work Mansfield (1980) using a dataset of 119 US manufacturing firms during the 1970s found a significant and direct relationship between the amount of basic research carried out by an industry or firm and its rate of increase of total factor productivity. These results were confirmed by Link (1981) who not only found that privately financed basic research increases a firm's productivity, but also basic research which is financed by the government. Based on the work of Mansfield (1980), Griliches (1986) provided further evidence that basic research appeared to be more important for productivity growth than other types of $R \& D$. To be more precise, 
he found a several hundred percent premium for basic research. These findings were also confirmed in the work of Lichtenberg and Siegel (1991) who also ascertained that a firm's investment in basic research has a strong effect on productivity growth while investment in other types of R\&D either has only a small impact or no effect at all on productivity growth. Contrary to these results, Hall and Mairesse (1995) explored the relationship of the different components of $\mathrm{R} \& \mathrm{D}$ on productivity within a sample of French manufacturing firms suggesting that basic research reduces overall productivity by 5 or 9 percent.

Nevertheless, all these studies adopt a high level of aggregation and do barely control interindustry differences in technological opportunity or appropriability. ${ }^{1}$ However, this is one of the most crucial points: basic research is less focused and more uncertain than the other types of $\mathrm{R} \& \mathrm{D}$ and, hence, in order to make these research efforts beneficial, the firm needs to draw on a large pool of knowledge for guidance (Tsang et al. 2008). Rosenberg (1990) states that basic research is most fruitful in high-tech industries since "high technology industries are continually throwing up problems, difficulties and anomalous observations that are most unlikely to occur outside of a high technology context". Moreover, the technological level of an industry is crucial for the ability of a firm to appropriate returns from R\&D and other innovative activities and to improve its overall performance. Especially for firms in the hightech industry where products and processes are continuously changing, $R \& D$ activities are a key contributor to secure and strengthen their competitiveness (Tsang et al. 2008).

Link (1981) has also shown that the propensity of conducting basic research is increasing when a firm belongs to a so-called high opportunity industry, such as pharmaceuticals, chemicals, computers, electric equipment etc.

Therefore it seems to be interesting to compare the effects of basic research in low-tech and high-tech industries, as the appropriability conditions may differ across these types of industries. Our study is, to the best of our knowledge, the first that combines the aspect of $R \& D$ productivity differences in high-tech and low-tech industries with the heterogeneity in R\&D (basic versus applied and development).

\footnotetext{
${ }^{1}$ Lim (2004) investigates the effects of basic and applied research on innovation output of firms in the pharmaceutical and the semiconductor industry which are both considered to belong to the high-tech sector. His results show that innovation in the pharmaceutical industry is closely tied to both basic and applied research whereas innovation in the semiconductor industry is mainly driven by applied research.
} 


\subsection{Theoretical Framework}

The starting point for our analysis is an extended Cobb-Douglas production function for firm $i$ at time $t$ which is common to most analyses of $\mathrm{R} \& \mathrm{D}$ contributions to productivity growth (e.g. Griliches 1979, Griliches and Mairesse 1984):

$Y_{i t}=A_{i t} L_{i t}^{\beta_{L}} C_{i t}^{\beta_{C}} K_{i t}^{\beta_{K}}$

where $Y_{i t}$ is the quality weighted output (value added or sales), $L_{i t}$, and $C_{i t}$ denote the inputs labour and physical capital and $K_{i t}$ describes the knowledge capital of firm $i$ in period $t$. In addition $A_{i t}$ is a measure for the total factor productivity (TFP) which increases the marginal products of the other production factors simultaneously. The knowledge stock is described by a firm's R\&D capital stock hence $K_{i t}=R D_{i t}$ with $\beta_{K}=\beta_{R D}$. The parameters $\beta_{L}, \beta_{C}$ and $\beta_{R D}$ denote the unknown output elasticities of inputs.

Our main question of interest is whether different types of $R \& D$, especially basic research show different potential regarding the generation of productivity effects in the high-tech and the low-tech industry.

Following Griliches (1986) we can extend our framework by disentangling R\&D into basic research $(B R)$ and applied research and development which we label as one component $(A D)$ indicating that the unweighted $\mathrm{R} \& \mathrm{D}$ capital stock of a firm is the sum of both, hence $R D=B R+A D$. We assume that investment in basic research exhibits a possible premium or discount $\gamma$, which leads to the following weighted capital stock $R D^{*}$ :

$R D^{*}=(1+\gamma) B R+A D=B R+\gamma B R+A D=\left(1+\gamma \frac{B R}{R D}\right) R D=(1+\gamma s) R D$

where $s$ is the share of basic research (BR) in total $R D=B R+A D$.

As usual, we take logarithms of equation (1) in order to estimate a Cobb Douglas function. Substituting with (2) gives the following linear regression equation:

$\log Y_{i t}=\beta_{0}+\beta_{L} \log L_{i t}+\beta_{C} \log C_{i t}+\beta_{R D} \log R D_{i t}^{*}+\varepsilon_{i t}$

with

$\log \left(A_{i t}\right)=\beta_{0}+\varepsilon_{i t}$ 
The disturbance term $\varepsilon_{i t}$ is further decomposed into an unobserved time specific effect $\alpha_{t}$ which is treated as fixed and captures time-specific effects which are common across all industries, an unobservable firm-specific component $\varpi_{i}$ and a random shock, $\mu_{i t}$. Hence,

$\varepsilon_{i t}=\alpha_{t}+\varpi_{i}+\mu_{i t}$

Furthermore, substituting $\log R D_{i t}^{*}$ with (2) yields:

$\log R D_{i t}^{*}=\log R D_{i t}+\log (1+\gamma s)=\log R D_{i t}+\log \left(1+\gamma \frac{B R_{i t}}{R D_{i t}}\right)$

The $\log R D^{*}$ term of equation (3) can thus be approximated ${ }^{2}$ by:

$\beta_{R D} \log R D_{i t}^{*} \square \beta_{R D} \log R D_{i t}+\beta_{R D} \gamma \frac{B R_{i t}}{R D_{i t}}$

which finally leads to

$$
\begin{aligned}
\log Y_{i t} & \approx \beta_{0}+\beta_{L} \log L_{i t}+\beta_{C} \log C_{i t} \\
& +\beta_{R D} \log R D_{i t}+\beta_{R D} \gamma \frac{B R_{i t}}{R D_{i t}}+\alpha_{t}+\varpi_{i}+\mu_{i t}
\end{aligned}
$$

The beta coefficients represent the output-input elasticities. Hence, the estimated parameter for the basic research share is defined as $\pi=\beta_{R D} \gamma$. To show whether 'BR' exhibits a premium or discount, we are interested in the parameter $\gamma$ in our model. To be more precise, if $\gamma>0$ 'BR' would show a premium and a discount if $\gamma<0$.

\section{Data, Econometric Methods, and Results}

\subsection{Database}

We use data from the Flemish Research and Development survey for our analysis. The Flemish R\&D survey is a biannual survey conducted on behalf of the Flemish government in order to compile comparable statistics for Eurostat and the OECD member states. This mainly quantitative survey covers most OECD countries with large harmonized questionnaire in order to compose the European Innovation Scoreboard with the collected data. The set-up

\footnotetext{
2 This log transformation is a valid measure for small numbers. The share of basic research in a firm's total internal R\&D expenditures is small and on average around 0.06 in our sample.
} 
of the Flemish $R \& D$ survey is inventory based: all potential $R \& D$ active companies are identified and surveyed. Moreover, the R\&D survey comprises a very detailed breakdown of firms' R\&D budgets which facilitates the calculation of the R\&D knowledge stock and corrections for the double-counting such as $\mathrm{R} \& \mathrm{D}$ employment which is included in both the labor input measure (number of employees) and the $R \& D$ expenditures or $R \& D$ employment variables $^{3}$. Firms are also asked for the breakdown of their internal R\&D spending into basic research, applied research and experimental development. This information enables us to create our key variable of interest, namely a firm's share of basic research in its total R\&D.

Our analysis is based on three consecutive waves of the Flemish R\&D survey data which covers the period from 2002 until 2007. The R\&D data are supplemented with information from the BELFIRST database which contains data on financial indicators for Belgian firms. Each year, the majority of Belgian firms are legally bound to file their annual accounts at the Central Balance Sheet Office in order to provide third parties with reliable information on their financial health, employment and general development (Sels et al., 2006). Subsequently, these data are added to the BELFIRST database, an electronic database containing financial information on Belgian companies and businesses. As a result, this database provides detailed information on the financial performance of Belgian firms.

Our analysis only includes companies which belong to the manufacturing sector. Furthermore, we just take firms into account which showed at least once a positive number of total R\&D employees in the observation period from 2002 until 2007. In order to correct for outliers etc. we applied cleaning procedures similar to the ones proposed by Hall and Mairesse (1995), i.e. we trimmed outliners in both levels and growth rates, removed observations for which the double-counting corrections accounted for more than 50 percent of the total value and required that value added is positive.

The dependent variable in our analysis is a firm's value added (VA). Following, amongst others, Terleckyj (1974), Cuneo and Mairesse (1984) and Kaiser (2002) we have considered a firm's yearly number of R\&D employees as a proxy variable for the $R \& D$ stock. $R \& D$ employment may also best represent tacit knowledge which plays an important role in the R\&D process since tacit knowledge is embedded in the capabilities of a firm's workforce (Kaiser 2002).

\footnotetext{
${ }^{3}$ For a discussion about arising biases caused by double-counting see e.g. Schankerman (1981).
} 
Following equation (5) our input measures are the number of employees (EMPL), tangible assets $(A S S E T S)$, the number of $\mathrm{R} \& \mathrm{D}$ employees $(R D)$ and the basic research share of $\mathrm{R} \& \mathrm{D}$ expenditures $(B R / R D)$. Following our model derived in the previous section (equation (5)) $V A, E M P L, A S S E T S$ and $R D$ enter the equation in logarithms. As suggested by the literature (Schankerman 1981, Hall and Mairesse 1995) the number of employees is corrected for double-counting by subtracting R\&D employment from employment ${ }^{4}$.

Based on their NACE code information ${ }^{5}$ each firm is assigned to a total of 13 different industry classes (see Table 1). On basis of the OECD classification these industries are assigned to either the low- or the medium/high-tech sector. Sectors that fall into the classification of low-tech industries are food and tobacco, textile, wood and furniture, paper, rubber and plastic, metal, building and construction as well as miscellaneous industry. Hence, chemicals, pharmaceuticals, machines and equipment, computer, electronic and optical products, instruments as well as transport are labeled as high-technology industries. Griliches and Mairesse (1984) ${ }^{6}$ divide firms into scientific and non-scientific subgroups in their database. The so-called scientific firms are firms which belong to the chemical, drug, computer, electronics, and instrument industries. This classification corresponds strongly to our grouping between high and low-tech sectors which therefore also allows us to label our firms operating in the high-tech sector as scientific and our firms based in the low-tech industry as non-scientific firms.

\footnotetext{
${ }^{4}$ In a robustness check we also used $R \& D$ expenditures instead of $R \& D$ employment as a proxy variable for the knowledge stock of a firm which then consequently also requires the double-counting correction for value added and the capital variable as well. On the one hand this is performed by adding the material component of R\&D expenditures back into a firm's added value. Furthermore, capital investment is also subtracted by R\&D expenditures since a firm's investment also includes expenditures which are due to the physical investment used in the R\&D process (e.g. lab equipment, building etc.).

${ }^{5}$ Our full data set only provides us with the NACE code at the two-digit level. The NACE codes are the standard classification scheme of economic activities used in the European Community. The detailed classification of the different industries can be found in Table 1.

${ }^{6}$ See also Cuneo and Mairesse (1984) as well as Basant and Fikkert (1996) for a similar grouping.
} 
Table 1 Industry Classification and Frequency Distribution

\begin{tabular}{|c|c|c|c|c|}
\hline Industry & NACE rev. 2008 & Description & Frequency & $\%$ \\
\hline 1 & $10,11,12$ & Food and Tobacco & 104 & 10.99 \\
\hline 2 & $13,14,15$ & Textiles, Clothing and Leather & 77 & 8.14 \\
\hline 3 & 16,31 & Wood and Furniture & 29 & 3.07 \\
\hline 4 & 17,18 & Paper & 35 & 3.70 \\
\hline 5 & 19,20 & Chemicals & 109 & 11.52 \\
\hline 6 & 21 & Pharmaceuticals & 27 & 2.85 \\
\hline 7 & 22 & Rubber and Plastic & 60 & 6.34 \\
\hline 8 & $24,25,33$ & Metal & 92 & 9.73 \\
\hline 9 & 27,28 & Machines and Equipment & 202 & 21.35 \\
\hline 10 & 26 & $\begin{array}{l}\text { Computers, Electronic and Optical } \\
\text { Products, Instruments }\end{array}$ & 63 & 6.66 \\
\hline 11 & 29,30 & Transport & 40 & 4.23 \\
\hline 12 & 41 & Building and Construction & 29 & 3.07 \\
\hline 13 & $1,5,23,37,35,32$ & Miscellaneous Industry & 79 & 8.35 \\
\hline Total & & & 946 & 100.00 \\
\hline
\end{tabular}

After elimination of data with missing values in variables of interest our final sample consists of 353 firms in an unbalanced panel with 946 firm-year observations.

All variables in monetary units are measured in thousand Euros in prices of the year 2000. We used the GDP deflator for price adjustment. Table 1 shows the descriptive statistics for all variables. It can be clearly seen that firms' value added is on average more than 2.5 times higher for companies located in the high-tech segment than for firms based in the low-tech industries. In companies from the low-tech sector, however, the average of physical capital is only slightly lower than for firms operating in the high-tech industry. The descriptive statistics also reveal that the average firm based in the high-tech industry is larger (405 employees) than the average company based in the low-tech sector (254 employees). Regarding a firm's knowledge capital, companies operating in high-tech have on average a four times higher $R \& D$ stock than firms located in the low-tech segment. By contrast, the share of basic research in a firm's R\&D is slightly higher for firms operating in low-tech than 
for companies operating in high-tech industries ${ }^{7}$. However, a test reveals that these values do not differ significantly from each other. The difference between low and high tech sectors becomes apparent if one looks at the absolute numbers of basic research instead of percentages. There the high tech sector firms clearly spend much more on basic research than firms low tech sectors (knowledge stock of basic research of 2.92 in high-tech sectors vs. 0.88 in low-tech). It has also to be taken into account, that the data of the basic research share variable is rather skewed.

Note that $R \& D$ and the basic research share enter equation (5) with a one-year lag, as, at the very earliest, any result of R\&D activity may only reach the market after a year, certainly not in the same year. Of course, the time period between an R\&D project and the implementation of its results into the market may be longer than one year in reality. On the one hand, it would be desirable to experiment with longer lag lengths in the regressions, but this is not possible with our data as our time series dimension is rather short and the panel is unbalanced. We thus run into small sample problems quickly. On the other hand, however, this problem should not be too severe for our regressions, as we use the R\&D stock and not a flow measure. As Mansfield (1980) has shown that it is very likely that there is a high correlation of past basic research values with current values of (basic) research, our stock measure should be a good proxy also for lagged values.

Moreover, there are 45 observations in our sample which have a zero value for the $R \& D$ variable. Since our estimation model requires the logarithm of this variable and the logarithm of zero values is not defined, we set the values of $\ln (R D)$ to zero in these cases. As commonly done in the literature (e.g. Hall and Ziedonis 2001, Czarnitzki et al. 2009) we include a dummy variable $D(R D=0)=1$, zero otherwise. This captures the arising bias from the missing value imputation. As a consequence, we do not have to discard these observations. Note that the estimated coefficients of $D(R D=0)$ have no interpretation in itself. Instead of zero, we could also have imputed -9999 , for instance, and the estimate of the slope of R\&D would be numerically identical. Then $D(R D=0)$ would just have different coefficients due to the arbitrary choice of the imputation value.

\footnotetext{
${ }^{7}$ Although these numbers may be surprising at first sight, data from other countries (e.g. Austria) also show that the share of basic research is lower in the high (3.67\%) than in the low-tech sector (4.71\%) (Statistik Austria 2009).
} 
Table 2 Descriptive Statistics

\begin{tabular}{|c|c|c|c|c|c|c|}
\hline Variable & Description & & Mean & Std. Dev. & Min & $\operatorname{Max}$ \\
\hline \multirow[t]{3}{*}{$V A_{i t}$} & \multirow[t]{3}{*}{ Value added } & Full & $34,317.95$ & $111,415.30$ & 76 & $1,459,809$ \\
\hline & & HighTech & $50,900.90$ & $156,255.90$ & 123 & $1,459,809$ \\
\hline & & LowTech & $19,833.97$ & $38,841.58$ & 76 & 329,323 \\
\hline \multirow[t]{3}{*}{$\operatorname{ASSETS}_{i, t}$} & \multirow{3}{*}{$\begin{array}{l}\text { Physical capital } \\
\text { measured as } \\
\text { firms' tangible } \\
\text { assets }\end{array}$} & Full & $18,876.02$ & $73,851.11$ & 13 & 876,749 \\
\hline & & HighTech & $20,113.04$ & $65,095.44$ & 13 & 705,499 \\
\hline & & LowTech & $17,795.77$ & $80,773.67$ & 22 & 876,749 \\
\hline \multirow[t]{3}{*}{$E M P L_{i, t}$} & \multirow{3}{*}{$\begin{array}{l}\text { Number of } \\
\text { employees }\end{array}$} & Full & 324.12 & 615.03 & 1 & 4,074 \\
\hline & & HighTech & 404.90 & 779.30 & 1 & 4,074 \\
\hline & & LowTech & 253.57 & 410.31 & 2 & 3,283 \\
\hline \multirow[t]{3}{*}{$R D_{i, t-1}$} & \multirow{3}{*}{$\begin{array}{l}\text { Knowledge stock } \\
\text { measured as } \\
R \& D \text { employment }\end{array}$} & Full & 29.40 & 120.70 & 0 & 1,662 \\
\hline & & HighTech & 48.62 & 172.11 & 0 & 1,662 \\
\hline & & LowTech & 12.63 & 29.17 & 0 & 272 \\
\hline \multirow[t]{3}{*}{$B R / R D_{i, t-1}$} & \multirow{3}{*}{$\begin{array}{l}\text { Share of basic } \\
\text { research in firms } \\
\text { total } R \& D\end{array}$} & Full & 0.06 & 0.13 & 0 & 1 \\
\hline & & HighTech & 0.06 & 0.12 & 0 & 0.81 \\
\hline & & LowTech & 0.07 & 0.14 & 0 & 1 \\
\hline
\end{tabular}

Note: Time and industry dummies not presented. Value added and tangible assets are measured in thousand Euros in prices of the year 2000 .

\subsection{Estimation Method}

Estimating the coefficients of a production function is not a trivial task as many problems, such as unobserved heterogeneity and endogeneity may occur and could bias the results. Unobserved heterogeneity is most likely to arise since some unobservable variables such as e.g. managerial ability also influence the creation of the value added of a firm.

Intuitively, this issue can be tackled by applying panel econometric methods like fixedeffects estimators (e.g. the within or the first-difference estimator) which control for firmspecific, unobserved effects. However, a major drawback of these standard panel estimators is that they only lead to consistent parameter estimates if the assumption of strict exogeneity holds. That is, it requires the regressors to be uncorrelated with past, present, and future shocks and thus, rules out any feedback effects from a firm's output in period $t$ to future values of labor, physical and knowledge capital. This assumption is most likely to be violated 
in our analysis since one should expect that a firm's sales also influence its future decisions on R\&D activities, labor and capital investments.

A test on strict exogeneity proposed by Wooldridge (2002) which can be easily conducted by adding lead values of the right-hand side variables (excluding time and industry dummies) to the fixed-effects within model reveals that the explanatory variables suffer from feedback effects. Hence, the strict exogeneity assumption does not hold.

Therefore, we apply a linear feedback model which relaxes the strict exogeneity assumption and relies only on sequential exogeneity, and thus allows for feedback effects of future values of $\mathrm{Y}$ on the $\mathrm{X}$ variables. This model had been originally introduced by Blundell et al. (1995, 2002) for count data models. They have argued that the main source of unobserved heterogeneity lies in the different values of the dependent variable (value added in our case) with which firms enter the sample. The model approximates the unobserved heterogeneity by including the pre-sample period average of $\ln (V A)$ in a standard pooled cross-sectional model. Lach and Schankerman (2008) have adapted the model for the linear regression model which we use here. We required at least five pre-sample observation values to construct our pre-sample mean $\ln \left(P R E_{-} Y\right)$.

\section{Test on Endogeneity}

Scholars estimating production functions are typically concerned about endogeneity of factor inputs. It was first mentioned by Marschak and Andrews (1944) that the estimation may suffer from a simultaneity problem since productivity also influences the factor input decision of a firm. Consequently, we test for endogeneity using a regression-based test following Hausman $(1978,1983)$ (see Wooldridge, 2002: 118-122, for a summary).

Performing this endogeneity test requires instrumental variables for each potentially endogenous regressor that are (a) exogenous - meaning they are uncorrelated with any unobserved factors affecting the firms' output; (b) relevant - meaning that they have strong partial correlation with the endogenous regressor to avoid weak instrument bias. According to Staiger and Stock (1997) a partial F-value of the instrumental variables in the first stage regression should exceed a value of ten.

We test for endogeneity of all our four regressors simultaneously. Therefore, each potentially endogenous regressor is regressed on all instrumental variables in the first step. As common 
in the literature, we use lagged values of the regressors as instruments. We use the first and second lag here. In addition, we also use industry level averages of the regressors as instrument. The key assumption behind industry level instruments is that the unobserved firm characteristics do not significantly affect the industry variables (see e.g. Jaffe, 1986).

The test on relevance supports the choice of the instruments. The partial F-statistics of our 12 instrumental variables are 4294.22 in the first-stage regression for employment, 1914.99 for assets, 855.95 for R\&D employment and 30.40 for the basic research share. Thus we are confident that our instruments are relevant.

Next, we obtain the residuals from our four first-stage regressions and add them to the equation of the production function (see equation (5)). An F-test on joint significance of the four residual vectors did not reject the Null hypothesis that our regressors are exogenous $(\mathrm{F}=$ 1.01 , p-value $=0.40)$.

Finally, we test whether our instruments are exogenous employing the Sargan test, or in our case the heteroscedasticity-robust version known as Hansen's $J$ test on overidentifying restrictions. The statistic does not reject the Null hypothesis of validity of instruments $\left[\chi^{2}(8)\right.$ $=6.598, \mathrm{p}$-value $=0.58)$.

Although not presented in detail here, the same results also hold for the subsamples of firms in low-tech and high-tech industries. Therefore, we proceed without instrumenting our righthand side variables in the econometric analysis below. ${ }^{8}$

\section{Empirical Results}

First we estimate the models for the full sample, i.e. including all sectors for comparison with prior work (e.g. Mansfield 1980, Griliches 1986). The coefficient of $\ln (\mathrm{RD})$ measured in t-1 shows the estimated elasticity of the R\&D knowledge stock with respect to a firm's output, i.e. added value. Our results show that an increase in the R\&D knowledge stock by 1 percent leads to an increase of 0.13 percent ( 0.17 percent in the pooled cross sectional model) in the full sample.

\footnotetext{
${ }^{8}$ However, we acknowledge that this is a limitation of our study. Although we pass all tests concerning the instruments, the economic arguments about simultaneity between productivity and choice of factor input levels apply. It may just be the case that our data is not rich enough to uncover endogeneity as our sample is relatively small. We suggest further research in the concluding section.
} 
We allow for a premium or discount of basic research in the portion of $B R / R D$ as outlined in equation 1.5. In order to conclude whether basic research exhibits a premium, we have to derive the structural equation coefficients from the reduced form coefficients as outlined in section 3 .

We test whether $\mathrm{H}_{0}: \gamma=\pi / \beta_{\mathrm{RD}}=0$

which is a direct test for a premium of basic research. We obtain standard errors using the delta method and find that $\gamma=1.556$ (p-value $=0.058$ ) in the pooled cross-sectional model and 1.330 (p-value=0.035) in the fixed effects regression. Thus, like the studies of Mansfield (1980) and Griliches (1986) we find a direct effect of basic research on a firm's productivity.

Nevertheless, a different view emerges when we split our sample in firms from high-tech and low-tech industries. We find an estimated and highly significant $\gamma$ of 2.858 in the pooled cross-sectional model and $\gamma=3.318$ by applying the panel estimator for firms operating in the high-tech sector. This means that an investment in basic research results in a premium that is around three times higher than the contribution of applied research and development towards a firm's productivity in the high-tech industry. This result is also reflected by looking at the slope of the $(\mathrm{BR} / \mathrm{RD})_{\mathrm{t}-1}$ coefficient and the elasticity of the R\&D knowledge stock. While a firm's value added increases around 0.5 percent if it raises its share on $R \& D$ devoted to basic research by 1 percent, an increase of the amount of total (internal) $R \& D$ expenditures by 1 percent only raises firm output by around 0.2 percent.

By contrast, looking at the results for the low-tech sector indicates a $\gamma$ of -0.199 (pvalue $=0.820)$ in the pooled cross-sectional model and a $\gamma$ of -0.037 (p-value $=0.976)$ in the panel model. Hence, we do not find a significant effect of basic research. Note that we also report the Wald test on the difference of the coefficients of basic research in the high- and low-tech sample that clearly indicates that the coefficients are significantly different from each other.

The R\&D knowledge stock shows a highly significant effect in every specification. Our results also reveal that the coefficient for $R \& D$ is around 50 percent higher for companies based in the high-tech segment than for firms belonging to low-tech industries. However, a Wald-test reveals that the two coefficients do not significantly differ from each other. The existing literature (see section 2 for a short review) on productivity effects of R\&D in the low vs. high-tech industry does not provide a clear picture either. Although most of the authors 
found considerable differences of the output-R\&D elasticity across industries, tests reveal that in many cases the Null hypothesis of equal coefficients across sectors cannot be rejected. ${ }^{9}$

A firm's physical capital stock also contributes to its productivity. The coefficient of this variable is highly positive significant for the full as well as for the high-tech and the low-tech sample. Interestingly, the estimated elasticity is twice as large for firms operating in the lowtech sector than compared to companies from high-tech industries. Hence, doubling a firm's physical capital stock would lead to an output increase of more than 20 percent in low-tech industries while it would account only for about 10 percent for firms in the high-tech industry. A Wald test also reveals that these two coefficients significantly differ from each other.

The results also show that an increase in labor leads to a productivity increase which is higher for firms in high-tech than for companies in the low-tech segments. The regressions also indicate that value added is heterogeneous across industries, since the respective industry dummies are jointly significant in all specifications. Moreover, there are significant firmspecific effects as measured by the pre-sample output measures. Nevertheless, looking at our results Table 3 reveals that the pooled cross-sectional models yield similar results.

Finally, some readers might be interested in the value of disembodied technological change as captured by our time dummies. When using the full sample, we find that this figure amounts to about $14 \%$ over the whole 5 -year period, thus roughly about $3 \%$ per year.

As further robustness checks, we also performed the regressions without observations that had zero R\&D employment. Consequently, 45 firm-year observations were dropped from our regressions. The obtained results (see Table A 1 in the appendix) were in line with the regression results that are presented in the previous analysis. Furthermore, all regressions were run again by using internal $R \& D$ expenditures as a proxy variable for a firm's knowledge stock instead of R\&D employment. As Table A 2 in the appendix shows the results are robust and lead to quite similar results.

In a final step we split the sample into large, medium and small companies (see Table A 3) according to the official definition proposed by the European Commission. While we do find

\footnotetext{
${ }^{9}$ The test on coefficients ' equality across equations is typically not reported explicitly in the cited papers, but can be calculated from the presented results.
} 
a premium coefficient for medium and large sized firms located in the high-tech industry, the coefficient of basic research turns out to be insignificant in the sample of small firms. These regressions also show that the premium of basic research increases with firm size in high-tech sectors. This finding points to the presence of economies of scope. Larger firms can be expected to undertake more innovation projects than smaller firms, and thus use insights from basic research in potentially more applications that eventually lead to innovation and thus productivity growth. Thus, the larger the firm, the more returns it might be able to appropriate from its basic research findings. Regarding the low-tech sector we do not find a significant effect of basic research in any size class. 
Table 3 Regression Results

\begin{tabular}{|c|c|c|c|c|c|c|}
\hline \multirow[b]{2}{*}{ Variable } & \multicolumn{3}{|c|}{$\begin{array}{c}\text { FIXED EFFECTS PANEL } \\
\text { MODELS }\end{array}$} & \multicolumn{3}{|c|}{$\begin{array}{c}\text { POOLED CROSS SECTIONAL } \\
\text { MODELS } \\
\end{array}$} \\
\hline & $\begin{array}{c}\text { Full } \\
\text { Sample }\end{array}$ & $\begin{array}{l}\text { High-Tech } \\
\text { Sample }\end{array}$ & $\begin{array}{l}\text { Low-Tech } \\
\text { Sample }\end{array}$ & $\begin{array}{c}\text { Full } \\
\text { Sample }\end{array}$ & $\begin{array}{l}\text { High-Tech } \\
\text { Sample }\end{array}$ & $\begin{array}{l}\text { Low-Tech } \\
\text { Sample }\end{array}$ \\
\hline $\ln (A S S E T S)_{t}$ & $\begin{array}{c}0.160 * * * \\
(0.017)\end{array}$ & $\begin{array}{c}0.097 * * * \\
(0.026)\end{array}$ & $\begin{array}{c}0.210 * * * \\
(0.020)\end{array}$ & $\begin{array}{c}0.182 * * * \\
(0.019)\end{array}$ & $\begin{array}{c}0.101 * * * \\
(0.030)\end{array}$ & $\begin{array}{c}0.249 * * * \\
(0.020)\end{array}$ \\
\hline $\ln (E M P L)_{t}$ & $\begin{array}{c}0.520 * * * \\
(0.042)\end{array}$ & $\begin{array}{c}0.609 * * * \\
(0.071)\end{array}$ & $\begin{array}{c}0.458 * * * \\
(0.042)\end{array}$ & $\begin{array}{c}0.735 * * * \\
(0.021)\end{array}$ & $\begin{array}{c}0.811 * * * \\
(0.030)\end{array}$ & $\begin{array}{c}0.675^{* * *} * \\
(0.028)\end{array}$ \\
\hline $\ln (R D)_{t-1}$ & $\begin{array}{c}0.130 * * * \\
(0.016)\end{array}$ & $\begin{array}{c}0.155 * * * \\
(0.022)\end{array}$ & $\begin{array}{c}0.100 * * * \\
(0.021)\end{array}$ & $\begin{array}{c}0.170 * * * \\
(0.016)\end{array}$ & $\begin{array}{c}0.190 * * * \\
(0.022)\end{array}$ & $\begin{array}{c}0.143 * * * \\
(0.022)\end{array}$ \\
\hline$(B R / R D)_{t-1}$ & $\begin{array}{l}0.202^{*} \\
(0.102)\end{array}$ & $\begin{array}{c}0.515^{* * * *} \\
(0.142)\end{array}$ & $\begin{array}{l}-0.004 \\
(0.124)\end{array}$ & $\begin{array}{l}0.226^{*} \\
(0.103)\end{array}$ & $\begin{array}{c}0.542 * * * \\
(0.146)\end{array}$ & $\begin{array}{c}0.028 \\
(0.125)\end{array}$ \\
\hline$D(R D=0)_{t-1}$ & $\begin{array}{c}0.079 \\
(0.077)\end{array}$ & $\begin{array}{c}0.210 \\
(0.163)\end{array}$ & $\begin{array}{l}-0.007 \\
(0.085)\end{array}$ & $\begin{array}{c}0.136 \\
(0.084)\end{array}$ & $\begin{array}{c}0.233 \\
(0.176)\end{array}$ & $\begin{array}{c}0.075 \\
(0.093)\end{array}$ \\
\hline $\ln \left(P R E_{-} Y\right)$ & $\begin{array}{c}0.240 * * * \\
(0.043)\end{array}$ & $\begin{array}{c}0.209 * * \\
(0.066)\end{array}$ & $\begin{array}{c}0.258 * * * \\
(0.045)\end{array}$ & & & \\
\hline CONSTANT & $\begin{array}{c}2.988 * * * \\
(0.175)\end{array}$ & $\begin{array}{c}3.464 * * * \\
(0.295)\end{array}$ & $\begin{array}{c}2.788 * * * \\
(0.190)\end{array}$ & $\begin{array}{c}3.835 * * * \\
(0.111)\end{array}$ & $\begin{array}{c}4.333 * * * \\
(0.150)\end{array}$ & $\begin{array}{c}3.617 * * * \\
(0.131)\end{array}$ \\
\hline $\begin{array}{l}\text { Joint significance } \\
\text { of year dummies }\end{array}$ & $\begin{aligned} & \chi^{2}(4) \\
= & 2.98 * *\end{aligned}$ & $\begin{array}{l}\chi^{2}(4) \\
=2.22^{*}\end{array}$ & $\begin{array}{l}\chi^{2}(4) \\
=1.69\end{array}$ & $\begin{aligned} & \chi^{2}(4) \\
= & 2.20^{*}\end{aligned}$ & $\begin{array}{l}\chi^{2}(4) \\
=1.71\end{array}$ & $\begin{array}{l}\chi^{2}(4) \\
=1.37\end{array}$ \\
\hline $\begin{array}{l}\text { Joint significance } \\
\text { of industry } \\
\text { dummies }\end{array}$ & $\begin{aligned} & \chi^{2}(12) \\
= & 8.36^{* * * *}\end{aligned}$ & $\begin{aligned} & X^{2}(4) \\
= & 3.95^{* * *}\end{aligned}$ & $\begin{aligned} & \chi^{2}(7) \\
= & 8.16^{* * *}\end{aligned}$ & $\begin{aligned} & \chi^{2}(12) \\
= & 10.91 * * *\end{aligned}$ & $\begin{aligned} & \chi^{2}(4) \\
= & 11.06^{* * *}\end{aligned}$ & $\begin{aligned} & \chi^{2}(7) \\
= & 7.86^{* * *}\end{aligned}$ \\
\hline $\begin{array}{l}\gamma(=\text { premium } \\
\text { coef. })\end{array}$ & $\begin{array}{l}1.556^{*} \\
(0.821)\end{array}$ & $\begin{array}{l}3.318 * * * \\
(1.061)\end{array}$ & $\begin{array}{l}-0.037 \\
(0.129)\end{array}$ & $\begin{array}{l}1.330^{* *} \\
(0.630)\end{array}$ & $\begin{array}{l}2.858 * * * \\
(0.862)\end{array}$ & $\begin{array}{c}0.199 \\
(0.877)\end{array}$ \\
\hline $\begin{array}{l}\text { Wald Test on } \\
\gamma_{\text {HIGH }}=\gamma_{\text {LOW }}\end{array}$ & \multicolumn{3}{|c|}{$4.19 * *$} & & \multicolumn{2}{|c|}{$4.67 * *$} \\
\hline $\begin{array}{l}\text { Wald Test on } \\
\beta_{\mathrm{RD}}^{\mathrm{HIGH}}=\beta_{\mathrm{RD}}^{\mathrm{LOW}}\end{array}$ & \multicolumn{3}{|c|}{$3.31 *$} & & \multicolumn{2}{|c|}{2.21} \\
\hline $\begin{array}{l}\text { Wald Test on } \\
\beta_{\text {ASSETS }}^{\text {HIGH }}=\beta_{\text {ASSETS }}^{\text {LOW }}\end{array}$ & \multicolumn{3}{|c|}{$11.92 * * *$} & & \multicolumn{2}{|c|}{$17.17 * * *$} \\
\hline$R$-squared & 0.948 & 0.956 & 0.941 & 0.940 & 0.951 & 0.931 \\
\hline Observations & 946 & 441 & 505 & 946 & 441 & 505 \\
\hline
\end{tabular}

Note: Robust standard errors in parentheses. *** (**, *) indicate a significance level of $1 \%(5 \%, 10 \%)$. 


\section{Conclusion}

Our results have shown that there exists a premium for basic research on a firm's net output. Moreover, dividing our sample into firms based in low and high-tech industries indicates that there is a premium effect for firms operating in the high-tech sector which is more than twice as high as the effect we have found for basic research in the full sample. Additionally, our regression results reveal that there is neither a premium nor a discount effect of basic research in the low-tech industries.

Nevertheless, it has been stressed that low-tech industries are quite technology-intensive, because they are active users of high-technology in their production process. E.g. the wood industry works with complex optical systems for optimizing their output when cutting wood. The food sector reverts to research results obtained in microbiology and bacteriology in order to develop and produce their innovative products (e.g. functional food). And the textile sector works with technical textiles which are the result of basic research conducted in the chemical industry (Schibany et al. 2007). Hence, our results seem to confirm our initial expectation that the appropriability conditions for basic research are lower in low-tech sectors than in high-tech industries. This is quite plausible since high-tech companies have a larger knowledge stock leading to a higher absorptive capacity which makes them able to identify, understand and exploit basic research insights for relevant objectives within their company.

Our robustness test on different firm-size categories has furthermore shown that appropriability conditions may vary with firm size. As the premium for basic research increases with firm size, one can conclude that larger firms are better able to appropriate returns from basic research as they undertake more innovation projects that can make potentially use of basic research findings than smaller firms where their total R\&D may only consist of a single project.

As Mansfield (1980) already stressed, the premium of basic research may also reflect the tendency for applied research and development to be more effective when carried out in conjunction with some basic research activities. He also emphasized that basic research may serve as a proxy for long term $R \& D$ investment of a firm to some extent. Nevertheless, due to its risky and unspecific nature, basic research is most likely to be underfinanced by private firms. A recent study of Czarnitzki et al. (2011) reveals that (basic) research investment is more sensitive to the firms' operating liquidity than in development investments, indicating 
that firms have to rely even more on internal funds for financing their research compared to their development activities. They also stress that despite the special support for industrial research by the Flemish government (e.g. grants for basic and strategic research) policy makers may also behave similar to private lenders who may not want to finance projects with no direct commercial value. Taking the two results of these studies together suggests that policy makers might want to review current allocation mechanisms for public R\&D funding. This paper shows that basic research is a crucial component, especially for medium and larger-sized firms located in the high-tech industry to enhance their productivity and keep them competitive. Thus, firms may be aware of the benefits from basic research, but might have problems increase basic research efforts because of lack of finance both at the private credit market and with regard to the acquisition of subsidies. Therefore, the distribution of grants within public subsidy schemes should be analyzed carefully and possibly be readjusted towards basic research efforts rather than activities like prototyping and other development. The latter activities could possibly be financed on the private credit market, too, as they have immediate commercial goals and promise private returns in the not too distant future. For instance, product developments can be patent-protected, whereas basic research results are typically much more difficult to appropriate. In addition, basic research will not only affect the private returns of firms, but can also be expected to generate higher social benefits than other types of $R \& D$ such as experimental development. As maximizing the social benefits but not the private returns should be a goal of technology policy intervention in the market for $\mathrm{R} \& \mathrm{D}$, it seems appropriate to review current policy practice and to evaluate whether basic research in the corporate sector receives the adequate attention in subsidy schemes for the private sector, especially in high-tech industries.

Although our study provides some first insights into the productivity of basic research and its heterogeneous impact in low and high tech industries, the study is of course not without limitations. Our relatively small panel of firms prevented us unfortunately from applying other econometric techniques that scholars use nowadays for the estimation of production functions (see van Biesebroeck, 2007, 2008, for surveys). Although we tested for potential endogeneity and did not reject exogeneity, our data may not be rich enough to actually uncover the presence of endogeneity. In order to deal with potential endogeneity in production function estimation, scholars have used (dynamic) instrumental variable estimation, such as the GMM estimators proposed by Arellano and Bond (1991) or Blundell 
and Bond (1998), for instance. Alternative options would be the application of the Olley and Pakes (1996) or Levinsohn and Petrin (2003) methods. So far, there is no common opinion on how to include R\&D in these alternative models, though.

As the R\&D survey data that we used here, exist for many OECD countries since many years, it would be highly interesting to see further research on this topic with comparable but larger panels. Harmonized cross-country studies with larger panels would allow using different estimators and comparisons of the robustness of results. 


\section{References}

Andries P., A. Bruylant, D. Czarnitzki, M. Hoskens, S. Thorwarth and A. Wastyn (2009), O\&O-activiteiten van de Vlaamse bedrijven, in: Debackere K. and R. Veugelers (ed.), Vlaams Indicatorenboek Wetenschap, Technologie en Innovatie 2009 (Vlaamse Overheid, Brussel), pp. 53-68.

Arrow, K. (1962), Economic Welfare and the Allocation of Resources for Invention, in: Nelson, R. (Ed.), The Rate and Direction of Inventive Activity.

Arellano, M. and S. Bond (1991), Some tests of specification for panel data: Monte Carlo evidence and an application to employment equations, Review of Economic Studies 58, 277-297.

Basant, R. and B. Fikkert (1996), The effects of R\&D, foreign technology purchase, and domestic and international spillovers on productivity in Indian firms, Review of Economics and Statistics 78(2), 187-199

Blundell, R. and S. Bond (1998), Initial conditions and moment restrictions in dynamic panel data models, Journal of Econometrics 87, 115-143.

Blundell, R., R. Griffith and J. van Reenen (1995), Dynamic Count Data Models of Innovation, Economic Journal 105, 333-345.

Blundell, R., R. Griffith and F. Windmeijer (2002), Individual Effects and Dynamics in Count Data Models, Journal of Econometrics 108, 113-131.

Cassiman, B., D. Pérez-Castrillo and R. Veugelers (2002), Endogenizing know-how flows through the nature of R\&D investments, International Journal of Industrial Organization 20, 775-799.

Cohen, W. and D.A. Levinthal (1989), Innovation and Learning: The Two Faces of R\&D, Economic Journal 99, 569-596.

Cohen, W. and D.A. Levinthal (1990), Absorptive Capacity: A New Perspective on Learning and Innovation, Administrative Science Quarterly 35, 128-152.

Cuneo, P. and J. Mairesse (1984), Productivity and R\&D at the Firm Level in French Manufacturing, in Z. Griliches (ed.), $R \& D$, Patents and Productivity, Chicago: University of Chicago Press, 339-374.

Czarnitzki, D., H. Hottenrott and S. Thorwarth (2011), Industrial Research versus Development Investment: The Implications of Financial Constraints, Cambridge Journal of Economics 35(3), 527-544.

Czarnitzki, D., K. Kraft and S. Thorwarth (2009), The Knowledge Production of 'R' and 'D', Economics Letters 105, 141-143.

David, P.A., B.H. Hall and A.A. Toole (2000), Is public R\&D a complement or substitute for private R\&D? A review of the econometric evidence, Research Policy 29, 497-529.

Griliches, Z. (1979), Issues in Assessing the Contribution of Research and Development to Productivity Growth, Bell Journal of Economics 10, 92-116. 
Griliches, Z. and J. Mairesse (1984), Productivity and R\&D at the Firm Level, in: Z. Griliches (ed.), R\&D, Patents and Productivity, Chicago: University of Chicago Press, 339-374.

Griliches, Z. (1986), Productivity, R\&D and basic research at the firm level in the 1970s', American Economic Review 76(1), 141 - 154.

Hall, B.H. and J. Mairesse (1995), Exploring the Relationship between R\&D and Productivity in French Manufacturing Firms, Journal of Econometrics 65, 263 - 293.

Hall, B.H. and R.H. Ziedonis (2001), The Patent Paradox Revisited: an Empirical Study of Patenting in the U.S. Semiconductor Industry, 1979-1995, RAND Journal of Economics $32(1), 101-128$.

Hall, B.H., J. Mairesse and P. Mohnen (2010), Measuring the Returns to R\&D, in: B.H. Hall, and N. Rosenberg (eds.), Handbook of the Economics of Innovation, Vol. 2, Elsevier, 1033-1082.

Harhoff, D. (1998), R\&D and Productivity in German Manufacturing Firms, Economics of Innovation and New Technology 6, 29-49.

Hausman, J.A. (1978), Specification Tests in Econometrics, Econometrica 46, 1251-1271.

Hausman, J. (1983), Specification and Estimation of Simultaneous Equations Models, in: Z. Griliches and M.D. Intriligator (eds.), Handbook of Econometrics, Vol. 1, Amsterdam: North Holland, 391-448.

Henard, D.H. and M.A. McFadyen (2005), The complementary roles of applied and basic research: a knowledge-based perspective, Journal of Product Innovation Management 22, 503-514.

Jaffe, A.B. (1986), Technological Opportunity and Spillovers of R\&D: Evidence from Firms' Patents, Profits, and Market Value, American Economic Review 76(5), 984-1001.

Kaiser, U. (2002), Innovation, Employment, and Firm Performance in the German Service Sector, ZEW Economic Studies, Vol. 16, Heidelberg/New York.

Kafourous, M. (2005), R\&D and Productivity Growth: Evidence from the UK, Economics of Innovation and New Technology 14(6), 479 - 497.

Lach, S. and M. Schankerman (2008), Incentives and invention in universities, RAND Journal of Economics 39(2), 403-433.

Levinsohn, J. and A. Petrin (2003), Estimating Production Functions using Inputs to Control for Unobservables, Review of Economic Studies 70, 317 - 341.

Lichtenberg, F.R and D. Siegel (1991), The Impact of R\&D Investment on Productivity-New Evidence Using Linked R\&D-LRD Data, Economic Inquiry 29(2), 203-29.

Link, A.N. (1981), Basic Research and Productivity Increase in Manufacturing: Some Additional Evidence, American Economic Review 71(5), 1111-1112.

Mairesse, J. and M. Sassenou (1991), R\&D and Productivity: A Survey of Econometric Studies at the Firm Level, Science-Technology-Industry Review 8, 317-348.

Mansfield, E. (1980), Basic research and productivity increase in Manufacturing, American Economic Review 70, 863-873. 
Marschak, J. and W. Andrews (1944), Random Simultaneous Equations and the Theory of Production, Econometrica 12, 143 - 205.

Nelson, R. R. (1959), The Simple Economics of Basic Scientific Research, Journal of Political Economy 67, University of Chicago Press, 297-306.

OECD (1993), Frascati-Manual, Proposed Standard Practice for Surveys of Research and Experimental Development, Paris: Organisation for Economic Co-Operation and Development.

Olley, S., and A. Pakes (1996), The Dynamics of Productivity in the Telecommunications Equipment Industry, Econometrica 64, 1263 - 1298.

Pavitt, K. (1991), What makes basic research economically useful?, Research Policy 20, 109119.

Rosenberg, N. (1990), Why do firms do basic research (with their own money)?, Research Policy 19, 165-174.

Schankerman, M. (1981), The Effect of Double Counting and Expensing on the Measured Returns to R\&D, Review of Economics and Statistics 63, 454-458.

Schibany, A., H. Gassler and G. Streicher (2007), High-Tech or Not-Tech - Vom fehlenden Strukturwandel und anderen Sorgen, Johanneum Research InTeReg Working Paper No. 35, Vienna.

Sels, L., S. De Winne, J. Maes, J. Delmotte, D. Faems and A. Forrier (2006), Unraveling the HRM-Performance link: value-creating and cost-increasing effects of small business HRM, Journal of Management Studies 43, 319-342.

Staiger, D. and J. Stock (1997), Instrumental variables regression with weak instruments, Econometrica 65(3), 557-586.

Statistik Austria (2009), Erhebung über Forschung und experimentelle Entwicklung (F\&E) 2007, (online availaible at: http://www.statistik.at).

Terleckyj, N.E. (1974), Effects of R\&D on the Productivity Growth of Industries: An Exploratory Study, Washington, D.C.: National Planning Association.

Trajtenberg, M., R. Henderson and A. Jaffe (1992), Ivory Tower Versus Corporate Lab: An Empirical Study of Basic Research and Appropriability, NBER Working Paper No. 4146, Cambridge.

Tsai, K.-H. and Wang J.-C. (2004), R\&D Productivity and the Spillover Effects of High-Tech Industry on the Traditional Manufacturing Sector: The Case of Taiwan, The World Economy 27(4), 1555-1570.

Tsang, E.W.K., P.S.L. Yipb, M. H. Tohc (2008), The impact of R\&D on value added for domestic and foreign firms in a newly industrialized economy, International Business Review 17, 423-441.

Van Biesebroeck, J. (2007), Robustness of productivity estimates, Journal of Industrial Economics 55(3), 529-569.

Van Biesebroeck, J. (2008), The sensitivity of productivity estimates: Revisiting three important productivity debates, Journal of Business and Economic Statistics 26(3), 311328. 
Verspagen, B. (1995), R\&D and Productivity: A Broad Cross-Section Cross-Country Look, Journal of Productivity Analysis 6, 117-135.

Wooldridge J.M. (2002), Econometric analysis of cross section and panel data, Cambridge: MIT Press. 


\section{Appendix}

Al Further Robustness Checks

Table A 1 Regressions results without $\mathbf{R D}_{\mathrm{t}-1}=\mathbf{0}$

\begin{tabular}{|c|c|c|c|}
\hline & & Panel Estimations & \\
\hline & Full Sample & High-Tech Sample & Low-Tech Sample \\
\hline $\ln (A S S E T S)_{t}$ & $\begin{array}{c}0.159 * * * \\
(0.017)\end{array}$ & $\begin{array}{c}0.0974 * * * \\
(0.026)\end{array}$ & $\begin{array}{c}0.209 * * * \\
(0.020)\end{array}$ \\
\hline $\ln (E M P L)_{t}$ & $\begin{array}{c}0.510 * * * \\
(0.043)\end{array}$ & $\begin{array}{c}0.600 * * * \\
(0.071)\end{array}$ & $\begin{array}{c}0.444 * * * \\
(0.041)\end{array}$ \\
\hline $\ln (R D)_{t-1}$ & $\begin{array}{c}0.143 * * * \\
(0.016)\end{array}$ & $\begin{array}{c}0.165^{* * * *} \\
(0.023)\end{array}$ & $\begin{array}{c}0.111 * * * \\
(0.021)\end{array}$ \\
\hline$(B R / R D)_{t-1}$ & $\begin{array}{l}0.188 * \\
(0.101)\end{array}$ & $\begin{array}{l}0.514 * * * \\
(0.141)\end{array}$ & $\begin{array}{l}-0.0323 \\
(0.124)\end{array}$ \\
\hline $\ln \left(P R E_{-} Y\right)$ & $\begin{array}{c}0.235^{* * * *} \\
(0.043)\end{array}$ & $\begin{array}{l}0.204 * * * \\
(0.066)\end{array}$ & $\begin{array}{c}0.255^{* * * *} \\
(0.044)\end{array}$ \\
\hline CONSTANT & $\begin{array}{l}3.080 * * * \\
(0.175)\end{array}$ & $\begin{array}{c}3.506 * * * \\
(0.293)\end{array}$ & $\begin{array}{c}2.894 * * * \\
(0.191)\end{array}$ \\
\hline $\begin{array}{l}\gamma(=\text { premium } \\
\text { coef. })\end{array}$ & $\begin{array}{l}1.322 * \\
(0.737)\end{array}$ & $\begin{array}{l}3.111 * * * \\
(0.983)\end{array}$ & $\begin{array}{l}-0.291 \\
(1.118)\end{array}$ \\
\hline$R$-squared & 0.948 & 0.957 & 0.941 \\
\hline Observations & 901 & 426 & 475 \\
\hline
\end{tabular}

Note: Robust standard errors in parentheses. $* * *(* *, *)$ indicate a significance level of $1 \%(5 \%, 10 \%)$. All regressions include a full set of industry and time dummy variables. 
Table A 2 Regressions with Internal R\&D Expenditures instead of $R \& D$ Employment

\begin{tabular}{|c|c|c|c|c|c|c|}
\hline \multirow[b]{2}{*}{ Variable } & \multicolumn{3}{|c|}{ FIXED EFFECTS PANEL MODELS } & \multicolumn{3}{|c|}{$\begin{array}{c}\text { POOLED CROSS SECTIONAL } \\
\text { MODELS }\end{array}$} \\
\hline & $\begin{array}{l}\text { Full } \\
\text { Sample }\end{array}$ & $\begin{array}{l}\text { High-Tech } \\
\text { Sample }\end{array}$ & $\begin{array}{l}\text { Low-Tech } \\
\text { Sample }\end{array}$ & $\begin{array}{l}\text { Full } \\
\text { Sample }\end{array}$ & $\begin{array}{l}\text { High-Tech } \\
\text { Sample }\end{array}$ & $\begin{array}{l}\text { Low-Tech } \\
\text { Sample }\end{array}$ \\
\hline $\ln (A S S E T S)_{t}$ & $\begin{array}{l}0.153 * * * \\
(0.016)\end{array}$ & $\begin{array}{c}0.098 * * * \\
(0.024)\end{array}$ & $\begin{array}{c}0.198 * * * \\
(0.019)\end{array}$ & $\begin{array}{c}0.172 * * * \\
(0.018)\end{array}$ & $\begin{array}{c}0.100 * * * \\
(0.027)\end{array}$ & $\begin{array}{l}0.234 * * * \\
(0.020)\end{array}$ \\
\hline $\ln (E M P L)_{t}$ & $\begin{array}{l}0.525 * * * \\
(0.042)\end{array}$ & $\begin{array}{c}0.613 * * * \\
(0.070)\end{array}$ & $\begin{array}{c}0.459 * * * \\
(0.041)\end{array}$ & $\begin{array}{c}0.736 * * * \\
(0.019)\end{array}$ & $\begin{array}{c}0.796 * * * \\
(0.028)\end{array}$ & $\begin{array}{l}0.679 * * * \\
(0.026)\end{array}$ \\
\hline $\ln (R D)_{t-1}$ & $\begin{array}{l}0.098 * * * \\
(0.011)\end{array}$ & $\begin{array}{c}0.127 * * * \\
(0.018)\end{array}$ & $\begin{array}{c}0.075^{* * *} \\
(0.013)\end{array}$ & $\begin{array}{c}0.127 * * * \\
(0.012)\end{array}$ & $\begin{array}{l}0.156^{* * *} \\
(0.019)\end{array}$ & $\begin{array}{l}0.100 * * * \\
(0.014)\end{array}$ \\
\hline$B R / R D_{t-1}$ & $\begin{array}{l}0.192 * \\
(0.102)\end{array}$ & $\begin{array}{c}0.487 * * * \\
(0.143)\end{array}$ & $\begin{array}{l}-0.018 \\
(0.126)\end{array}$ & $\begin{array}{c}0.213 * * \\
(0.103)\end{array}$ & $\begin{array}{c}0.504^{* * * *} \\
(0.145)\end{array}$ & $\begin{array}{c}0.010 \\
(0.126)\end{array}$ \\
\hline$D(R D=0)_{t-1}$ & $\begin{array}{l}0.374 * * * \\
(0.093)\end{array}$ & $\begin{array}{l}0.647 * * \\
(0.196)\end{array}$ & $\begin{array}{l}0.205^{*} \\
(0.103)\end{array}$ & $\begin{array}{c}0.518 * * * \\
(0.101)\end{array}$ & $\begin{array}{l}0.782 * * * \\
(0.214)\end{array}$ & $\begin{array}{l}0.347 * * \\
(0.109)\end{array}$ \\
\hline $\ln \left(P R E_{-} Y\right)$ & $\begin{array}{l}0.233 * * * \\
(0.042)\end{array}$ & $\begin{array}{c}0.193 * * \\
(0.065)\end{array}$ & $\begin{array}{c}0.255^{* * *} \\
(0.044)\end{array}$ & & & \\
\hline CONSTANT & $\begin{array}{l}2.768 * * * \\
(0.162)\end{array}$ & $\begin{array}{c}3.144 * * * \\
(0.267)\end{array}$ & $\begin{array}{c}2.668 * * * \\
(0.183)\end{array}$ & $\begin{array}{c}3.505 * * * \\
(0.097)\end{array}$ & $\begin{array}{c}3.858^{* * *} \\
(0.115)\end{array}$ & $\begin{array}{l}3.417 * * * \\
(0.124)\end{array}$ \\
\hline \multirow{2}{*}{$\begin{array}{l}\text { Joint significance } \\
\text { of year dummies }\end{array}$} & $\chi^{2}(4)$ & $\chi^{2}(4)$ & $\chi^{2}(4)$ & $X^{2}(4)$ & $X^{2}(4)$ & $\chi^{2}(4)$ \\
\hline & $=2.60 * *$ & $=2.37 * *$ & $=1.46$ & $=1.99 *$ & $=1.99^{*}$ & $=1.21$ \\
\hline \multirow{2}{*}{$\begin{array}{l}\text { Joint significance } \\
\text { of industry } \\
\text { dummies }\end{array}$} & $\chi^{2}(12)$ & $\chi^{2}(4)$ & $\chi^{2}(7)$ & $\chi^{2}(12)$ & $\chi^{2}(4)$ & $\chi^{2}(7)$ \\
\hline & $=8.60 * * *$ & $=3.43 * * *$ & $=9.45^{* * *}$ & $=10.83 * * *$ & $=8.91 * * *$ & $=9.33 * * *$ \\
\hline $\begin{array}{l}\gamma(=\text { premium } \\
\text { coef. })\end{array}$ & $\begin{array}{l}1.955^{*} \\
(1.083)\end{array}$ & $\begin{array}{c}3.848^{* * * *} \\
(1.291)\end{array}$ & $\begin{array}{l}-0.238 \\
(1.664)\end{array}$ & $\begin{array}{l}1.677 * * \\
(0.839)\end{array}$ & $\begin{array}{c}3.233 * * * \\
(1.029)\end{array}$ & $\begin{array}{c}0.104 \\
(1.264)\end{array}$ \\
\hline $\begin{array}{l}\text { Wald Test on } \\
\gamma_{\mathrm{HIGH}}=\gamma_{\mathrm{LOW}}\end{array}$ & \multicolumn{4}{|c|}{$3.76^{* *}$} & \multicolumn{2}{|c|}{$3.69 * *$} \\
\hline $\begin{array}{l}\text { Wald Test on } \\
\beta_{\mathrm{RD}}^{\mathrm{HIGH}}=\beta_{\mathrm{RD}}^{\mathrm{LOW}}\end{array}$ & \multicolumn{4}{|c|}{$5.08^{* *}$} & \multicolumn{2}{|c|}{$5.40 * *$} \\
\hline$R$-squared & 0.949 & 0.957 & 0.943 & 0.942 & 0.953 & 0.932 \\
\hline Observations & 946 & 441 & 505 & 946 & 441 & 505 \\
\hline
\end{tabular}

Note: Robust standard errors in parentheses. $* * *(* *, *)$ indicate a significance level of $1 \%(5 \%, 10 \%)$. 
Table A 3 Regressions for different firm size (small, medium and large)

\begin{tabular}{|c|c|c|c|c|c|c|}
\hline & \multicolumn{3}{|c|}{ HIGH-TECH SECTOR } & \multicolumn{3}{|c|}{ LOW-TECH SECTOR } \\
\hline & Small & Medium & Large & Small & Medium & Large \\
\hline $\ln (A S S E T S)_{t}$ & $\begin{array}{c}0.115 * * * \\
(0.033)\end{array}$ & $\begin{array}{l}-0.010 \\
(0.046)\end{array}$ & $\begin{array}{c}0.146 * * * \\
(0.033)\end{array}$ & $\begin{array}{c}0.235^{* * * *} \\
(0.037)\end{array}$ & $\begin{array}{c}0.220 * * * \\
(0.032)\end{array}$ & $\begin{array}{c}0.149 * * * \\
(0.032)\end{array}$ \\
\hline $\ln (E M P L)_{t}$ & $\begin{array}{c}0.409 * * * \\
(0.084)\end{array}$ & $\begin{array}{c}0.619 * * * \\
(0.094)\end{array}$ & $\begin{array}{c}0.546 * * * \\
(0.075)\end{array}$ & $\begin{array}{c}0.631 * * * \\
(0.091)\end{array}$ & $\begin{array}{c}0.377 * * * \\
(0.083)\end{array}$ & $\begin{array}{c}0.250 * * * \\
(0.056)\end{array}$ \\
\hline $\ln (R D)_{t-1}$ & $\begin{array}{c}0.240 * * * \\
(0.057)\end{array}$ & $\begin{array}{c}0.268 * * * \\
(0.038)\end{array}$ & $\begin{array}{c}0.100 * * * \\
(0.032)\end{array}$ & $\begin{array}{l}-0.0407 \\
(0.057)\end{array}$ & $\begin{array}{c}0.106 * * * \\
(0.030)\end{array}$ & $\begin{array}{c}0.137 * * * \\
(0.023)\end{array}$ \\
\hline$B R / R D_{t-1}$ & $\begin{array}{l}-0.057 \\
(0.241)\end{array}$ & $\begin{array}{c}0.685^{* * * *} \\
(0.164)\end{array}$ & $\begin{array}{c}0.828 * * * \\
(0.273)\end{array}$ & $\begin{array}{l}-0.289 \\
(0.233)\end{array}$ & $\begin{array}{c}0.015 \\
(0.213)\end{array}$ & $\begin{array}{l}-0.098 \\
(0.169)\end{array}$ \\
\hline$D(R D=0)_{t-1}$ & $\begin{array}{l}-0.238^{*} \\
(0.143)\end{array}$ & $\begin{array}{c}0.212 \\
(0.163)\end{array}$ & $\begin{array}{c}0.537 * * * \\
(0.145)\end{array}$ & $\begin{array}{l}-0.220^{*} \\
(0.112)\end{array}$ & $\begin{array}{c}0.123 \\
(0.134)\end{array}$ & $\begin{array}{c}0.463 * * * \\
(0.102)\end{array}$ \\
\hline $\ln \left(P R E_{-} Y\right)$ & $\begin{array}{c}0.315 * * * \\
(0.065)\end{array}$ & $\begin{array}{c}0.099 \\
(0.079)\end{array}$ & $\begin{array}{l}0.291 * * * \\
(0.062)\end{array}$ & $\begin{array}{c}0.072 \\
(0.081)\end{array}$ & $\begin{array}{c}0.228 * * * \\
(0.067)\end{array}$ & $\begin{array}{c}0.321 * * * \\
(0.054)\end{array}$ \\
\hline CONSTANT & $\begin{array}{c}3.028 * * * \\
(0.358)\end{array}$ & $\begin{array}{l}4.815 * * * \\
(0.452)\end{array}$ & $\begin{array}{c}2.436 * * * \\
(0.384)\end{array}$ & $\begin{array}{c}3.503 * * * \\
(0.423)\end{array}$ & $\begin{array}{c}3.229 * * * \\
(0.439)\end{array}$ & $\begin{array}{c}3.842 * * * \\
(0.325)\end{array}$ \\
\hline $\begin{array}{l}\gamma \quad(=\text { premium } \\
\text { coef. })\end{array}$ & $\begin{array}{l}-0.235 \\
(0.983)\end{array}$ & $\begin{array}{c}2.553 * * * \\
(0.701)\end{array}$ & $\begin{array}{c}8.303 * * * \\
(3.908)\end{array}$ & $\begin{array}{c}7.103 \\
(11.201)\end{array}$ & $\begin{array}{c}0.139 \\
(2.017)\end{array}$ & $\begin{array}{c}-0.719 \\
(1.236)\end{array}$ \\
\hline Observations & 110 & 192 & 139 & 111 & 189 & 205 \\
\hline$R$-squared & 0.866 & 0.753 & 0.924 & 0.856 & 0.701 & 0.890 \\
\hline
\end{tabular}

Note: Robust standard errors in parentheses. $* * *(* *, *)$ indicate a significance level of $1 \%(5 \%, 10 \%)$. All regressions include a full set of industry and time dummy variables. 